\title{
Peran forda IPTTM dalam memperkenalkan kebudayaan Toraja di Kota Malang
}

\author{
Nida Khoirunisa, Audria Octavia Sri Anjani, Salsabillah Malicha Putri, Nanda \\ Harda Pratama Meiji* \\ Universitas Negeri Malang, Jl. Semarang No. 5 Malang, Jawa Timur, Indonesia \\ * Penulis korespondensi, Surel: nanda.harda.fis@um.ac.id
}

Paper received: 03-01-2021; revised: 15-01-2021; accepted: 30-01-2021

\begin{abstract}
Regional student organizations are organizations formed through a group of students who come from one area and have the same goal. Forda IPTTM (Tongkonan Toraja Malang Youth Association) is a form of regional student organization that has the same goal among its members, namely as a communication for Toraja students who have migrated in Malang. This research focuses on how the role of Forda IPTTM in introducing Toraja culture in Malang. This study uses a qualitative approach and is described descriptively by providing a detailed description of the problem formulation in the study. In analyzing research problems, researchers used Max Weber's theory of social action and the concept of status and role. The results showed that students who have status as members and administrators have rights and obligations that must be carried out for the success of the goals of the establishment of Forda IPTTM. The role of Forda IPTTM in introducing Toraja culture is manifested through the activities and work programs they have carried out, namely participating in cultural exhibitions by presenting Toraja dances and participating in the Universitas Brawijaya Cultural Village Festival, as well as promoting Toraja culture through social media.
\end{abstract}

Keywords: Forda IPTTM; Toraja culture; social action; status and role.

\begin{abstract}
Abstrak
Organisasi mahasiswa daerah ialah sebuah organisasi yang terbentuk melalui beberapa kumpulan mahasiswa yang berasal dari satu daerah dan memiliki tujuan yang sama. Forda IPTTM (Ikatan Pemuda Tongkonan Toraja Malang) merupakan salah satu bentuk organisasi mahasiswa daerah yang memiliki tujuan yang sama antar anggotanya yakni sebagai komunikasi mahasiswa Toraja yang merantau di Malang. Penelitian ini berfokus pada bagaimana peran Forda IPTTM dalam memperkenalkan kebudayaan Toraja di Malang. Peneliti menggunakan pendekatan kualitatif dan penelitian dijelaskan secara deskriptif dengan cara memberi gambaran terperinci mengenai rumusan masalah dalam penelitian. Dalam menganalisis permasalahan penelitian, teori yang digunakan peneliti adalah teori tindakan sosial Max Weber serta konsep status dan peran. Hasil penelitian menunjukkan bahwa mahasiswa yang memiliki status sebagai anggota maupun pengurus memiliki hak dan kewajiban yang harus dijalankan demi keberhasilan tujuan berdirinya Forda IPTTM. Peran Forda IPTTM dalam memperkenalkan kebudayaan Toraja diwujudkan melalui program kerja dan kegiatan yang telah mereka lakukan yakni mengikuti pameran budaya dengan menampilkan tarian Toraja dan mengikuti Festival Kampung Budaya Universitas Brawijaya, serta mempromosikan kebudayaan Toraja melalui media sosial.
\end{abstract}

Kata kunci: Forda IPTTM; kebudayaan Toraja; tindakan sosial; status dan peran.

\section{Pendahuluan}

Organisasi mahasiswa daerah yaitu sebuah organisasi yang terbentuk melalui beberapa kumpulan mahasiswa yang berasal dari satu daerah dan memiliki tujuan yang sama. Menurut Setiya, D. T (2018) anggota yang ada dalam organisasi mahasiswa daerah yaitu para mahasiswa yang merantau, mereka mempunyai tujuan dalam mengikuti organisasi yaitu agar 
mendapat keluarga baru, mengetahui teman-teman perantauan, tidak mau kehilangan bahasa daerahnya, serta ingin berpartisipasi dalam memperkenalkan budaya daerah asal kepada lingkungan baru yang mereka tempati melalui organisasi mahasiswa daerah yang diikuti. Hal ini sebagaimana forda IPTTM yang merupakan sebuah organisasi untuk menghimpun anggotanya dalam memenuhi tujuan bersama.

Forda IPTTM (Forum Daerah Ikatan Pemuda Tongkonan Toraja Malang) adalah sebuah forum yang menjadi sarana komunikasi mahasiswa Toraja yang berada di Malang. Forda IPTTM dirikan tahun 2002 yang dimulai dengan sekumpulan anak Toraja yang sering melakukan nongkrong kemudian membentuk sebuah forum. Dalam kegiatannya Forda IPTTM sering berpartisipasi dalam berbagai event salah satunya Kampung Budaya yang dilaksanakan di Universitas Brawijaya sebagai ajang bagi organisasi mahasiswa daerah dalam memperkenalkan kebudayaan asal mereka. Berdasarkan fenomena yang sudah dipaparkan, peneliti tertarik untuk mengkaji lebih dalam peran IPTTM dengan fokus penelitian kepada peran Forda IPTTM dalam mengenalkan dan melestarikan kebudayaan Toraja di lingkungan baru atau tanah rantu.

Dalam menunjukkan kebaharuan penelitian ini, penulis memaparkan beberapa penelitian terdahulu memiliki kemiripan dengan permasalahan yang dikaji oleh penulis. Pembanding utama penelitian ini adalah penelitian dari Rahmadani, S (2018) Penelitian tersebut berisi tentang bagaimana upaya UKM Teater Hampa Indonesia dalam melestarikan kesenian teater di lingkup Universitas Negeri Malang. Upaya pelestarian yang dilakukan UKM Teater Hampa Indonesia antara lain : 1) memberikan informasi kepada para anggota melalui rapat anggota, 2) mempublikasikan kegiatan yang telah dilakukan Teater Hampa Indonesia melalui beberapa akun media sosial, 3) memeberikan pelatihan dan pendidikan kepada anggota dan masyarakat, 4) membina skill para anggota sanggar supaya dapat melestarikan dan menhembangkan kesenian teater, 5) aktif mengikuti festival-festival lomba teater baik lingkup regional maupun nasional, 6)mengadakan pementasan seperti Pentas Produksi atau pementasan tahunan oleh UKM Teater Hampa Indonesia.

Pembanding kedua adalah penelitian dari Yulianita, N. D (2019) Fokus penelitian tersebut adalah upaya komunitas Cemandi Art dalam melestarikan kebudayaan yang berada di Desa Cemandi yaitu Tari Reog Cemandi. Upaya yang dilakukan Komunitas Cemandi Art dalan melestarikan Tari Reog Cemandi antara lain: 1) menyebarkan informasi terkait Tari Reog Cemandi di media sosial, 2) mengajarkan Tari Reog Cemandi kepada anak-anak di Desa Cemandi, 3) menggelar seni pertunjukan Tari Reog Cemandi seperti pada saat Hari Ulang Tahun Kabupaten Sidoarjo, festival, pawai, dan kegiatan desa.

Pembanding ketiga adalah penelitian dari Putra, B. D. P (2014). Penelitian tersebut berisi tentang komunikasi promosi pemerintah daerah dalam memperkenalkan batik khas Jonegoroan kepada masyarakat Kabupaten Bojonegoro (studi pada Disperingdang Kabupaten Bojonegoro. Hasil penelitian menunjukkan bahwa komunikasi promosi pemerintah daerah dalam memperkenalkan batik khas Jonegoroan dilakukan sebagai bentuk kepedulian pemerintah daerah Kabupaten Bojonegoro untuk melaksanakan aktivitas komunikasi dalam mengenalkan produk batik kepada masyarakat secara menyeluruh. Bentuk strategi komunikasi yang dilakukan meliputi: 1) Melalui galeri Dekranasa 2) Melalui butik dan toko yang ada di Bojonegoro 3) Melalui event pameran baik lokal, regional, dan nasional 4) Melalui 
event kange yune 5) Memberikan kewajiban kepada seluruh pegawai negeri di lingkungan Kabupaten Bojonegoro untuk menggunakan batik di lingkungan pemerintah.

Pembanding keempat adalah penelitian dari Styffany, L (2017) Penelitian tersebut berisi tentang bagaimana peran sanggar budaya patriarki loka dalam melestarikan nilai kearifan lokal melalui seni pedalangan. Peran Sanggar Budaya Patriarki Loka Kota Blitar antara lain: 1) mewariskan seni pedalangan melalui upaya kegiatan pelatihan seni pedalangan maupun seni yang lain, 2) mengembangkan seni pedalangan melakukan upaya dengan cara mengadakan pementasan di dalam sanggar dan diluar sanggar.

Pembanding kelima adalah penelitian dari Ellysa, V. A (2017). Penelitian tersebut berisi tentang bagaimana peran komunitas Turonggo Nogo dalam pelestarian kesenian jaranan reog thik di Desa Bekiring Kecamatan Pulung Kabupaten Ponorogo. Peran komunitas Turonggo Nogo Puspito antara lain: 1) setiap Sabtu dan Selasa malam melakukan kegiatan gladhen atau latihan kesenian jaranan reog thik, 2) melakukan pementasan sebanyak empat kali. Peran yang dijalankan oleh komunitas Turonggo Nogo Puspito dalam melestarikan kesenian jaranan reog thik tidak luput dari kendala yang dihadapi adalah kurangnya peralatan gamelan, kostum dan properti untuk melakukan pementasan.

Perbedaan penelitian ini dengan penelitian sebelumnya yaitu jika penelitian sebelumnya berfokus pada sanggar dan komunitas dalam melestarikan budaya melalui kesenian. Sedangkan, penelitian ini berfokus pada forum daerah yang memiliki peran dalam memperkenalkan kebudayaan Toraja melalui festival Kampung Budaya. Penelitian ini penting dikaji mengingat pentingnya peran generasi muda dalam melestarikan kebudayaan daerah di tengah masuknya berbagai kebudayaan asing yang terus menerus menjadi tantangan bagi Indonesia. Dalam hal ini peran organisasi mahasiswa sangat diharapkan dalam memotivasi generasi muda agar tetap mencintai budaya daerah sehingga budaya daerah tetap lestari. Melalui acara-acara yang diselenggarakan baik oleh pemerintah maupun organisasi mahasiswa daerah sendiri diharapkan dapat mendorong partisipasi generasi muda untuk terus mencintai budaya daerah sekaligus menjadi unjuk kreativitas generasi muda.

\section{Metode}

Dalam penelitian ini peneliti menggunakan pendekatan kualitatif. Creswell, J.W $(2014,56)$ mendefinisikan penelitian kualitatif sebagai rangkaian kegitan dalam menafsirkan secara material yang membuat dunia terlihat, dimana dalam penelitian kualitatif bermula dari asumsi dan kerangka penafsiran yang membentuk studi tentang permasalahan riset terkait dengan makna yang dikenakan pada manusia secara individu maupun kelompok pada suatu permasalahan sosial yang dibahas. Peneliti menggunakan pendekatan kualitatif ini untuk menentukan cara mencari, mengelolah serta menganalisis data pada hasil penelitian tersebut. Penelitian ini akan dijelaskan secara deskriptif. Jenis penelitian deskriptif mampu memberi gambaran secara rinci mengenai persoalan atau jawaban atas pertanyaan dalam penelitian (dalam Neuman, W. L, 2013).

Penelitian ini dilakukan di sekretariat Forda IPTTM tepatnya di Jalan Bendungan Sengguruh No 11 A Malang. Waktu penelitian dilakukan pada bulan Maret-April 2020. Penelitian ini menggunakan sampel non probably sampling dengan jenis purposive sampling. Peneliti menggunakan sampel tersebut karena peneliti memiliki tujuan tertentu untuk mendapatkan data yang memfokuskan pada peran organsasi mahasiswa daerah terutama Forda IPTTM dalam memperkenalkan kebudayaan Toraja di Kota Malang. Data yang 
dikumpulkan melalui cara observasi, wawancara, dan dokumentasi. Kegiatan observasi dilakukan untuk melihat gambaran umum tentang situasi di lapangan dan bagaimana kegiatan Forda IPTTM berlangsung. Selanjutnya, karena keterbatasan kondisi wawancara yang dilakukan oleh peneliti secara daring dengan memberikan google form dan video conference yang didukung dengan aplikasi whatsaap massenger dengan memberikan pertanyaan kepada informan mengenai topik penelitian. Dokumentasi dilakukan dengan cara mengumpulkan dokumen penting mengenai subjek penelitian yang berupa catatan riwayat organisasi, foto, video arsip organisasi dan sebagainya yang dibutuhkan untuk mendukung hasil wawancara. Sumber data yang digunakan dalam penelitian ini yaitu sumber data primer dan sumber data sekunder. Data primer merupakan data yang didapat langsung oleh peneliti melalui wawancara kepada informan yang mengerti tentang Forda IPTTM. Informan utama dalam penelitian ini adalah Ketua Forda IPTTM Periode 2020 yaitu Irthon Farli Rantetandung, dan Melitha selaku wakil ketua Forda. Dengan tiga informan pendukung yang menjadi bagian dari anggota Forda IPTTM yaitu Reinaldo Dengah, Rombelayuk Massudi Sumule, S.H, Ferriciano. Sedangkan data sekunder dalam penelitian ini berupa dokumen, buku, jurnal, dan lainnya yang berkaitan dengan peran Forda IPTTM dalam memperkenalkan kebudayaan Toraja di Kota Malang.

Menurut Sugiyono (2015:224) analisis data merupakan proses mencari serta menyusun secara sistematis data yang sudah diperoleh dari hasil observasi, wawancara, dan dokumentasi dan bahan lainnya yang mudah dipahami dan diinformasikan kepada orang lain. Teknik analisis data dilakukan dengan empat tahap, antara lain: pengumpulan data, reduksi data, penyajian data, dan penarikan kesimpulan. Pada tahap pengumpulan data peneliti menelaah seluruh data yang diperoleh di lapangan. Kemudian mencari data di lapangan untuk menjawab rumusan masalah dalam penelitian. Reduksi data dilakukan untuk menyeleksi data yang sesuai dengan fokus penelitian, untuk menegaskan, menajamkan, mengarahkan, dan menyisihkan data-data yang tidak perlu sehingga kesimpulan akhir dapat ditarik. Dalam penyajian data peneliti menyajiakan dalam bentuk narasi sesuai dengan aspek yang diteliti sehingga informasi dapat dengan jelas menjawab masalah yang diteliti. Dalam penarikan kesimpulan peneliti mencoba untuk menganalisis serta mencari makna dari data yang sudah dikumpulkan, sehingga mempermudah dalam menarik kesimpulan pada setiap proses kegiatan yang sedang berlangsung. Penelitian ini menggunakan cara triangulasi data, yang merupakan teknik pemeriksaan keabsahan data yang memanfaatkan sesuatu yang lain. Diluar data itu untuk melakukan pengecekan atau sebagai pembanding terhadap data itu (Moleong, L.J 2013:330).

\section{Hasil dan Pembahasan}

Organisasi mahasiswa daerah atau biasa yang disebut ormada adalah kelompok yang didasari oleh semangat kedaerahan, kesukuan, primordiaisme dengan sifat antar anggotanya berupa simpatik. Organisasi mahasiswa daerah memiliki fungsi sebagai sarana adaptasi serta untuk menjaga identitas budaya anggotanya. Organisasi mahasiswa daerah dapat memberikan suasana nyaman terhadap seluruh anggotanya sehingga para anggota berusaha dalam mempertahankan eksistensi kelompok tersebut. Sifat in-grup dalam organisasi tersebut sangat kuat hal itu karena mereka berusaha untuk mempertahankan kelompoknya (dalam Dwiantono N. A, 2013). Menurut Setiya, D. T(2018) semua anggota dalam organisasi mahasiswa daerah adalah para mahasiswa yang merantau, mereka mempunyai tujuan dalam mengikuti organisasi yaitu agar mendapat keluarga baru, mengetahui teman-teman perantauan, tidak mau kehilangan bahasa daerahnya, serta ingin berpartisipasi dalam memperkenalkan budaya 
daerah asal kepada lingkungan baru yang mereka tempati melalui organisasi mahasiswa daerah yang diikuti.

Forda IPTTM merupakan salah satu bentuk kelompok sosial in group. Menurut Soekanto, S dan Sulistyowati, B (2017) sikap in-group pada dasarnya diperoleh dari faktor simpati dan selalu memiliki perasaan rekat dengan anggota-anggota kelompoknya. Menurut Mayor Polak dalam Soekanto, S dan Sulistyowati, B (2017) perasaan in-group dan out-group atau perasaan dalam serta luar kelompok ialah dasar dari suatu sikap yang disebut etnosentrisme. Anggota dalam suatu kelompok sosial tidak jarang ditemukan adanya kecenderungan untuk menganggap bahwa segala sesuatu yang termasuk dalam kebiasaankebiasaan kelompoknya sendiri sebagai sesuatu yang terbaik jika dibandingkan dengan kebiasaan-kebiasaan kelompok lainnya.

Berdasarkan hasil wawancara dengan ketua Forda IPTTM tahun 2020, Irthon Farli Rantetandung menjelaskan bahwa berdirinya Forda IPTTM ini dilatarbelakangi oleh kerinduan mahasiswa Toraja yang merantau di Malang, untuk berhubungan baik dengan sesama mahasiswa Toraja, baik itu teman nongkrong, bekerja bersama, ataupun melestarikan dan memperkenalkan Budaya Toraja di Malang dan setiap mahasiswa Toraja yang melanjutkan pendidikan di Malang dapat dijangkau oleh forum ini sehingga dapat dengan mudah mencari informasi Kota Malang melalui IPTTM.. Forda IPTTM berdiri pada tahun 2002 diawali oleh para mahasiswa dan pelajar asal Toraja yang kerap mengadakan kumpul bersama (nongkrong) karena sama-sama dari daerah Toraja kemudian atas dukungan IKTTM (Ikatan Keluarga Tongkonan Toraja Malang) yang beranggotakan para orang tua yang berasal dari Toraja di Malang mendorong para mahasiswa untuk membentuk Forda IPTTM (Ikatan Pemuda Tongkonan Toraja Malang). Selama berdirinya Forda IPTTM telah melaksanakan berbagai kegiatan salah satunya dengan tujuan untuk memperkenalkan kebudayaan Toraja di Malang.

Peran Forda IPTTM dalam memperkenalkan kebudayaan Toraja di kota Malang antara lain mengikuti pameran budaya dengan menampilkan tarian Toraja, aksesoris, benda adat, lagu, serta kebiasaan Toraja baik melalui pameran budaya maupun dalam lingkungan pergaulan, mengikuti kegiatan tahunan seperti Kampung Budaya melalui kegiatan tersebut Forda IPTTM secara langsung memperkenalkan Adat dan budaya Toraja kepada Banyak Orang, dimana masih ada banyak orang yang belum mengetahui Toraja menjadi tahu karena keikutsertaan IPTTM dalam memperkenalkan Budaya Toraja, IPTTM juga memiliki akun Instagram dan Facebook yang mana kegiatan kegiatan dalam rangka memperkenalkan budaya Toraja akan di dokumentasikan ke akun sosial media tersebut sehingga mampu menjangkau lebih banyak orang lagi. Dan seiring waktu hingga saat ini anggota yang tergabung dalam Forda IPTTM bukan hanya mahasiswa dan pelajar yang berasal dari Toraja saja tapi jugaa mahasiswa yang tertarik untuk mempelajari kebudayaan Toraja juga. 


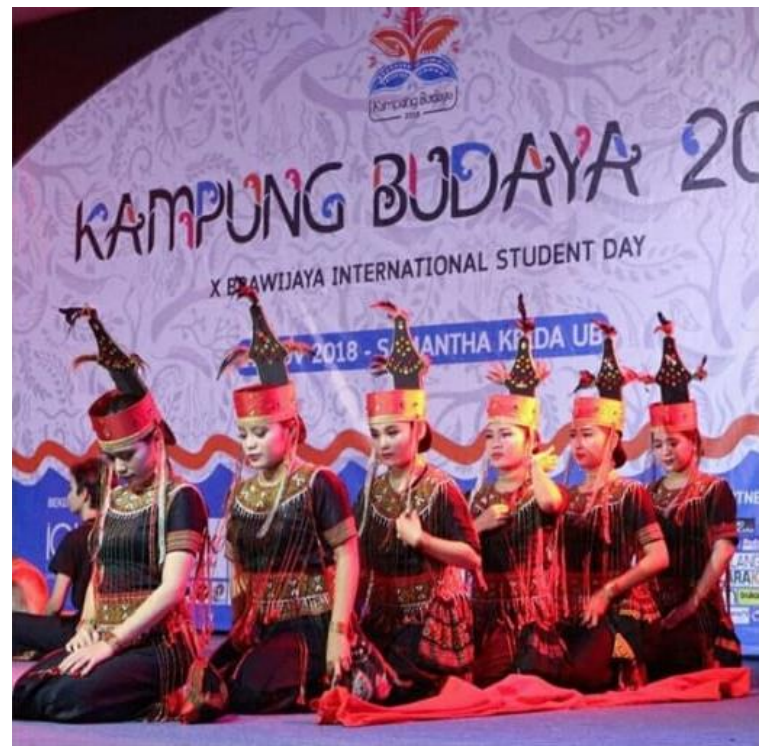

\section{Gambar 1. menunjukkan tarian Pa'gellu' Pia Toraya pada saat Kampung Budaya UB 2018 (dokumen milik Forda IPTTM)}

Penelitian ini akan dianalisis dengan teori tindakan sosial Max Weber yang dianggap selaras dengan topik yang dipilih. Teori tindakan sosial yang dikemukakan oleh Max Weber (dalam Wardana, K. A. A. K, 2017) merupakan perilaku individu yang memiliki arti tertentu bagi individu itu sendiri dan tindakan tersebut ditujukan kepada orang lain agar memperoleh respon dari orang lain. Menurut Wardana, K. A. A. K (2017) tindakan individu maupun kelompok berdasarkan pelakunya mengandung arti tertentu di dalamnya yang dapat dipahami oleh sang aktor yang meliputi beragam tindakan nyata. Tindakan nyata atas kesadaran status sosial mahasiswa yang berasal dari Toraja tersebut dengan pembentukan Forda IPTTM sebagai perwujudan kesadaran status mahasiswa Toraja terhadap kebudayaan mereka dan untuk memperkenalkan kebudayaan mereka di Kota Malang. Dalam temuan data dilapangan aktor yang dimaksud adalah anggota maupun pengurus dari Forda IPTTM. Mereka bergabung dengan Forda ini karena mempunyai makna subjektif yaitu berupa rasa kepedulian dan kebanggaan terhadap Suku dan Kebudayaan Toraja selain itu juga rasa kekeluargaan antara mahasiswa Toraja yang berkuliah. Sehingga mereka bergabung untuk melakukan tindakan nyata yaitu ikut dalam kegiatan-kegiatan yang diarahkan untuk mencapai tujuan didirikannya Forda IPTTM.

Status sosial menurut pandangan Ralph Linton (dalam Soekanto, S dan Sulistyowati, B, 2017:214) adalah seseorang yang memiliki hak dan kewajiban dalam kehidupan bermasyarakat. Dalam hal ini mahasiswa yang tergabung dalam Forda IPTTM menyadari statusnya sebagai mahasiswa yang berasal dari tanah Toraja kemudian mereka menyadari peran yang mereka miliki sebagai mahasiswa yang berasal dari Toraja yaitu memperkenalkan kebudayaan Toraja ke tanah rantau. Kemudian setelah bergabung dalam Forda IPTTM mereka menyandang status baik itu status sebagai anggota maupun sebagai pengurus. Status tersebut didapatkan dengan cara usaha (achieved status) dengan cara mendaftarkan diri untuk bergabung menjadi bagian dari Forda IPTTM. Mahasiswa yang memiliki status sebagai anggota maupun pengurus memiliki hak dan kewajiban yang harus dijalankan demi keberhasilan tujuan berdirinya Forda IPTTM. Salah satu hak yang didapatkan anggota maupun pengurus adalah mendapatkan perlakuan yang sama tanpa adanya senioritas antar anggota selain itu, 
setiap anggota akan dibantu apabila memiliki kesulitan sehingga kenyamanan dapat diperoleh. Sedangkan, salah satu bentuk kewajiban yang harus dijalankan yaitu ikut berpartisipasi terhadap kegiatan yang diselenggarakan Forda IPTTM selama satu tahun. Sedangkan peran menurut Ralph Linton (dalam Soekanto, S dan Sulistyowati, B 2017:212) adalah sebuah proses dari pelaksanaan semua hak dan kewajiban seseorang atas status sosial yang diemban dalam kehidupan bermasyarakat. Dalam hal ini, peran merupakan proses pelaksanaan dari status keanggotan maupun pengurus Forda IPTTM. Peran tersebut antara lain menjalankan dan berpartisipasi terhadap kegiatan yang akan diselenggarakan selama satu tahun, kegiatan tersebut antara lain kegiatan bakti sosial, kegiatan buka puasa bersama, kegiatan penyambutan mahasiswa baru, kegiatan olahraga bersama, mengikuti Festival Kampung Budaya Universitas Brawijaya Malang, bergabung dengan Forda lain untuk mengikuti pentas budaya, dan melaksanakan natal bersama.

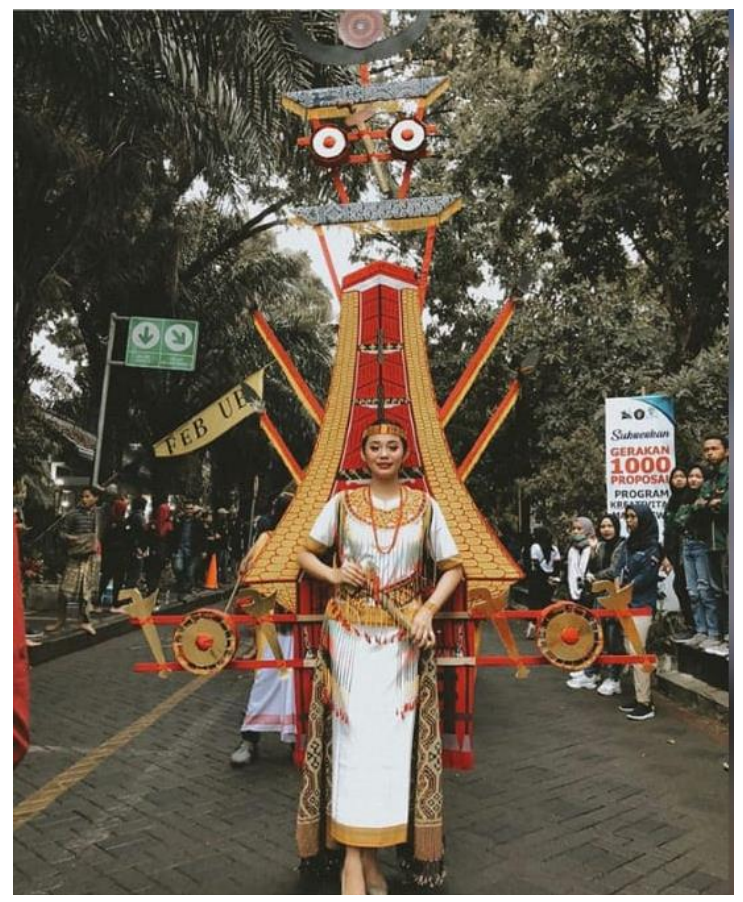

\section{Gambar 2. menunjukkan maskot Mangarara Banua pada saat parade Kampung Budaya UB 2019 (dokumen milik Forda IPTTM)}

Teori tindakan sosial terdiri dari 4 macam antara lain tindakan rasional instrumental, tindakan rasional berorientasi nilai, tindakan afektif, dan tindakan tradisional.

Pertama, Tindakan rasional alat-tujuan atau yang biasa disebut tindakan instrumental, tindakan ini didasarkan pada tujuan yang hendak diperoleh seseorang dalam lingkungan masyarakat, untuk memperoleh tujuan tersebut individu atau kelompok mempertimbangkan terlebih dahulu cara dan alat yang akan digunakannya (dalam Ritzer, G, 2012:215). Berdasarkan pernyataan tersebut, mahasiswa yang berasal dari tanah Toraja telah melakukan Tindakan rasional alat-tujuan yakni mereka berkeinginan memperkenalkan kebudayaan asal mereka dengan cara bergabung dalam Forda IPTTM. Dalam Forda IPTTM mereka dapat melaksanakan apa yang menjadi tujuan mereka tersebut misalnya mengikuti Festival Kampung Budaya Universitas Brawijaya, dengan tujuan untuk memperkenalkan kebudayaan Toraja baik itu berupa tarian maupun bentuk kebudayaan lainnya. 
Kedua, tindakan rasionalitas nilai, tindakan ini dilakukan dengan megedepankan nilai sosial (pandangan baik atau buruk) dalam masyarakat sehingga individu melakukannya dengan memperhitungkan secara rasional manfaat tindakannya namun mengesampingkan tujuan dari tindakan tersebut (dalam Ritzer, G, 2012:215). Dalam penelitian ini salah satu bentuk tindakan yang dilakukan Forda IPTTM adalah buka puasa bersama dan merayakan natal bersama, dimana kegiatan tersebut merupakan salah satu bentuk nilai religius yang dimilikinya berdasarkan kepercayaan masing-masing anggota maupun pengurus.

Ketiga, tindakan afektif adalah tindakan sosial yang bergantung dari segi emosional individu seperti rasa sedih, cinta, marah. Tindakan afektif ini muncul karena faktor perasaan individu sehingga tidak dapat diperkirakan dan dilakukan secara spontanitas tanpa pertimbangan yang matang (dalam Ritzer, G 2012:215). Dalam penelitian ini kegiatan afektif yang dilakukan oleh Forda IPTTM berdasarkan sikap empati terhadap sesama, hal tersebut terbukti dengan adanya kegiatan bakti sosial yang dilakukan setiap tahunnya.

Keempat, tindakan tradisional, tindakan ini dilaksanakan berdasarkan kebiasaan yang telah turun temurun dilakukan oleh masyarakat setempat sehingga individu cenderung melakukan tindakan tradisional tanpa ada pertimbangan terlebih dahulu (dalam Ritzer, G, 2012:215). Dalam hal ini, salah satu bentuk tindakan tradisional yang dilakukan Forda IPTTM dalam memperkenalkan kebudayaan Toraja sudah menjadi suatu kebiasaan yang dilakukan setiap tahunnya untuk menyambut mahasiswa baru dan menjalin keakraban sesame mahasiswa Toraja yang berkuliah di Malang.

\section{Simpulan}

Berdasarkan hasil penelitian mengenai peran Forda IPTTM dalam memperkenalkan kebudayaan Toraja di Kota Malang, dapat ditarik beberapa kesimpulan sebagai berikut: 1) Peran Forda IPTTM dalam memperkenalkan kebudayaan Toraja di kota Malang sangat penting Forda IPTTM sebagai wadah berhimpunnya mahasiswa dan pelajar yang berasal dari Toraja, melalui Forda IPTTM mereka dapat mengembangkan bakat dan minatnya serta turut andil dalam melestarikan kebudayaan lokal. 2) Peran Forda IPTTM dalam memperkenalkan kebudayaan Toraja di kota Malang terlihat dari wujud program kerja dan kegiata yang sudah mereka lakukan yakni mengikuti pameran budaya dengan menampilkan tarian Toraja dan mengikuti Festival Kampung Budaya Universitas Brawijaya, serta mempromosikan kebudayaan Toraja melalui media sosial. 3) Peran Forda IPTTM dalam memperkenalkan kebudayaan Toraja di kota Malang dapat dikaitkan dengan konsep status dan peran sebagai mahasiswa dan pelajar yang berasal dari tanah Toraja. Kemudian atas status tersebut Forda IPTTM memiliki peran yakni memperkenalkan kebudayaan Toraja melalui di Kota Malang. 4) Peran Forda IPTTM dalam memperkenalkan kebudayaan Toraja di kota Malang dapat dikaitkan dengan teori tindakan sosial Max Weber, dimana Forda IPTTM telah melakukan tindakan sosial rasional alat-tujuan. Forda IPTTM sendiri sebagai alat dalam memainkan perannya sebagai mahasiswa yang berasal dari Toraja sementara tujuan yang ingin mereka capai dengan tergabung ke dalam Forda IPTTM adalah salah satunya untuk memperkenalkan dan melestarikan kebudayaan Toraja di Kota Malang.

\section{Daftar Rujukan}

Creswell, J. W. (2014). Research Design: Pendekatan Kualitatif, Kuantitatif, dan Mixed Method. Yogyakarta: Pustaka Pelajar. 
Dwiantono, N. A. (2014). Makna Organisasi Mahasiswa Daerah (Ormada) Bagi Anggotanya (Studi deskriptif tentang peran ormada dalam menyikapi perbedaan Sosial-Budaya di antara Mahasiswa Universitas Airlangga. (Doctoral dissertation, Universitas Airlangga).

Ellysa, V. A. (2017). Peran Komunitas Turonggo Nogo Puspito dalam Pelestarian Kesenian Jaranan Reog Thik di Desa Bekiring Kecamatan Pulung Kabupaten Ponorogo. Skripsi tidak diterbitkan. Malang: FIS UM.

Moleong, L. J. (2013). Metode Penelitian Kualitatif. Bandung: Remaja Rosdakarya

Neuman, W. L. (2013). Metode Penelitian Sosial: Pendekatan Kualitatif dan Kuantitatif. Jakarta: PT Indeks.

Putra, B. D. P. (2014). Komunikasi Promosi Pemerintah Daerah dalam Memperkenalkan Batik Khas Jonegoroan Kepada Masyarakat Kabupaten Bojonegoro (Studi pada Disperingdang Kabupaten Bojonegoro) (Doctoral dissertation, University of Muhammadiyah Malang).

Rahmadani, S. (2018). Peran Anggota Sanggar UKM Teater Hampa Indonesia dalam Melestarikan Kesenian Teater di Universitas Negeri Malang. Skripsi tidak diterbitkan. Malang: FIS UM.

Ritzer, G. (2012). Teori Sosiologi dari Sosiologi Klasik Sampai Perkembangan Terakhir Postmodern. Yogyakarta: Pustaka Pelajar.

Setiya, D. T. (2019). Efektivitas Komunikasi Organisasi Mahasiswa Daerah Dalam Mensosialisasikan IAIN Salatiga (Studi Pada Imadisa Dan Imade Salatiga) (Doctoral dissertation, IAIN Salatiga).

Soekanto, S dan Sulistyowati, B. (2017). Sosiologi Suatu Pengantar Edisi Revisi. Jakarta: Rajawali Press.

Styffany, L. (2017). Peran Sanggar Budaya Patriarki Loka Kota Blitar dalam Melestarikan Nilai Kearifan Lokal melalui Seni Pedalangan. Skripsi tidak diterbitkan. Malang: FIS UM.

Sugiyono. (2015). Metode Penelitian Kombinasi (Mixhed Method). Bandung: Alfabeta.

Wardana, K. A. A. K. (2017). Tindakan Sosial Komunitas Save Street Child dalam Pemberdayaan Anak Jalanan di Kota Malang (Doctoral dissertation, Universitas Airlangga).

Yulianita, N. D. (2019). Upaya Komunitas Cemandi Art dalam Melestarikan Reog Cemandi di Desa Cemandi Kabupaten Sidoarjo. Skripsi tidak diterbitkan. Malang: FIS UM. 